\title{
KAN FORBRYDELSER FORUDSIGES? Om strategiske forbrydelser
}

\author{
AF FORSKNINGSCHEF, DR. JUR. BRITTA KYVSGAARD
}

A Swedish study on strategic offences, i.e. onset crimes that indicate a high probability of future offending, has identified offences and combinations of offences that tend to foreshadow long and intensive criminal careers. For example, the Swedish data suggest that if the two first convictions concern vehicle theft there is a 61 percent chance that the offender will become a chronic offender. These findings have attracted considerable attention in Denmark, and it therefore seems practical to try to validate them within the Danish context. Danish data, however, fail to replicate the results of the Swedish study, which may be at least partly attributable to the relatively small Danish sample. The Danish study emphasises, however, that even if one can identify combinations of offences/convictions indicating a high risk of future criminality, these combinations concern only a minor proportion of the chronic offenders. On the other hand, combinations indicating a low risk of future criminality concern a larger proportion of the chronic offenders. Seen in this perspective, the analysis of strategic offences seems of limited practical importance in predicting criminal careers. *

Forsøg på at forudsige recidiv har fundet sted siden kriminologiens barndom. Forklaringen herpå er oplagt: Hvis man med sikkerhed kan forudsige recidiv, har samfundet mulighed for at beskytte sig mod kriminalitet gennem forskellige typer af individualpræventive foranstaltninger. Interessen for prædiktionsstudier synes dog at have været noget svingende. Der var ganske megen forskning på området $\mathrm{i}$ mellemkrigstiden og i 1950'erne, hvor tiltroen til mulighederne for at skabe et godt og sikkert prædiktionsinstrument synes stor (for en oversigt, se Hurwitz og Christiansen 1971). Interessen for inkapaciteringsstudier i 1980'erne og 90'erne skabte atter nogen opmærksomhed omkring prædiktionsforskningen, idet en sikker forudsigelse af recidiv er forudsætningen for en effektiv selektiv inkapaciteringsstrategi (se fx Greenwood 1982; Cohen 1983; Andersson 1991).

For nylig har en svensk rapport, der også omhandler mulighederne for at forudsige kriminalitet, vakt en del opmærksomhed i Danmark. Det drejer sig om BRÄ-rapport nr. 3, 2000 om "Strategiska brott", som er udarbejdet af Robert Svensson med Jan Ahlberg som projektleder. Rapporten var central på det seneste årsmøde i Det Kriminalpræventive Råd, hvor Jan Ahlberg holdt et oplæg om rapporten. Dele af den svenske rapport er også oversat til dansk, og ikke helt sjældent refereres der til rapportens resultater i den offentlige debat.

* Title in English: Can Criminal Careers be Predicted on the Basis of "Strategic Offences." Original in Danish. 
Grunden til den danske interesse for undersøgelsen er - kort sagt - at den påviser, at arten af de første forbrydelser, en person begår, kan forudsige den videre kriminelle karriere. Unders $\emptyset$ gelsen adskiller sig fra de tidligere prædiktionsstudier ved at basere sig på oplysninger om de allerførste lovovertrædelser, hvilket selvsagt gør unders $\emptyset$ gelsens resultater mere interessant, da det drejer sig om så tidligt som muligt at kunne vurdere risikoen for fortsat kriminalitet. At en person, der tidligere er registreret for en meget stor mængde lovovertrædelser, har en stor risiko for fortsat kriminalitet, er så åbenbart af mindre kriminalpræventiv værdi.

I den danske debat om undersøgelsen har et enkelt resultat fra den svenske undersøgelse især været fremhævet, nemlig at personer, hvis første to straffe vedrører biltyveri, med $61 \%$ sandsynlighed bliver kronisk kriminelle. Det er klart, at resultater af denne art vækker opmærksomhed hos alle, der arbejder med at forebygge kriminalitet blandt børn og unge, da de kan være med til at fortælle, hvem man især bør være agtpågivende over for, og hvor man bør sætte ind.

Samtidig har der dog været nogen usikkerhed omkring resultaternes holdbarhed og relevans for Danmark. Er det de samme forbrydelser, der indikerer risiko for en omfattende kriminel karriere blandt lovovertrædere i Danmark?

Med henblik på at undersøge dette spørgsmål er resultaterne afprøvet på et dansk datamateriale.

\section{Problemstilling}

Strategiske forbrydelser er betegnelsen for debutkriminalitet, der indikerer en fortsat og omfattende kriminel karriere.

Både den svenske og den danske undersøgelse er baseret på oplysninger om den registrerede kriminalitet. Spørgsmålet er, om en registerbaseret undersøgelse med sikkerhed vil kunne udskille grupper med forskellige kriminalitetsfrekvenser, eftersom den registrerede kriminalitet kun udgør en mindre del af den faktiske kriminalitet. De undersøgelser, der belyser sammenhængen mellem den faktiske kriminalitet, en person begår (målt gennem selvrapporteringsundersøgelser), og personens registrerede kriminalitet, peger på, at der er konvergens her imellem (Farrington 2001; Weis 1986). Der synes derfor ikke at være væsentlige problemer ved at anvende den registrerede kriminalitet som indikator på personens kriminelle karriere.

Et væsentligere problem ved en undersøgelse af denne type er at afgøre, hvad der skal forstås med "debutkriminalitet". Hvad er egentlig personens første lovovertrædelse?

I den svenske undersøgelse er debutkriminalitet defineret som arten af den (hoved)sigtelse, personens første strafferetlige afgørelse vedrører. Hvis alle strafferetlige afgørelser alene omfattede ét forhold, ville en sådan afgrænsning være uproblematisk. Imidlertid omfatter en del strafferetlige afgørelse flere 
forhold, og nogle af disse forhold kan være begået inden den forbrydelse, der udgør hovedsigtelsen i et sagskompleks, begås.

Dette er ikke et uvæsentligt metodeproblem, idet det antagelig kan være tilfældigt eller varierende, i hvilket omfang kriminelle forhold samles i et sagskompleks, og dermed også tilfældigt/varierende, hvilken lovovertrædelse der bliver hovedsigtelsen. I hvert fald behøver den svenske praksis i så henseende ikke at svare til den danske.

Problemet forstærkes i meget høj grad af, at der i den svenske undersøgelse arbejdes med kombinationer af de to første forbrydelser (hovedsigtelser) med henblik på at kunne forudsige kriminalitet. De to første hovedsigtelser kan i tid ligge ganske langt fra hinanden, og der imellem kan personen være registreret for mange andre lovovertrædelser.

Disse forhold kan skabe et praktisk problem. Man må således udgå fra, at resultatet af en undersøgelse af denne art først og fremmest skal anvendes som et praktisk instrument, som myndighederne kan anvende med henblik på enkelt at skelne mellem unge med forskellig kriminalitetsrisiko. Men skal myndighederne afvente afgørelserne i de to første straffesager, før de kan afgøre, om en ung tilhører højrisikogruppen eller ej? Og er det altid let for myndighederne at fă oplysninger om, hvad der er hovedsigtelsen i et sagskompleks? Vil det ikke være mere naturligt for myndighederne at reagere på baggrund at oplysninger om de forbrydelser, de først får kendskab til/opdager?

Med henblik på at kunne belyse betydningen af forskellige definitioner af "debutkriminalitet" ses der i den danske undersøgelse også på, i hvilket omfang resultaterne ændres, hvis der - frem for at se på arten af første og anden hovedsigtelse - ses på arten af første og anden lovovertrædelse, vurderet ud fra gerningstidspunktet.

\section{Gerningsmandskategorier}

For at kunne undersøge sammenhængen mellem arten af de første lovovertrædelser og den senere kriminelle karriere er personerne i den svenske undersøgelse kategoriseret i følgende fire grupper efter antallet af strafferetlige afgørelser:

1) Engangskriminelle: personer, der alene er registreret for én strafferetlig afgørelse

2) Lejlighedskriminelle: personer, der er registreret for 2-3 strafferetlige afgørelser

3) Recidivister: personer, der er registreret for 4-8 strafferetlige afgørelser

4) Kronisk kriminelle: personer, der er registreret for 9 eller flere strafferetlige afgørelser.

En tilsvarende kategorisering er foretaget i den danske undersøgelse. 


\section{Det danske og det svenske undersøgelsesmateriale}

Den danske undersøgelse er baseret på et datamateriale, indsamlet til brug for en unders $\emptyset$ gelse af den kriminelle karriere (Kyvsgaard 1998). Unders $\emptyset$ gelsen omfatter et tilfældigt udsnit på en femtendedel af samtlige personer, der i perioden 1979-1991 blev registreret for en lovovertrædelse. Til brug for analysen af strategiske forbrydelser er udvalgt personer, der er født i årene 1964-1966. Det er sket for at sikre, at personernes kriminelle karriere har kunnet følges fra det fyldte 15. år, altså fra den kriminelle lavalder. Personerne i de 3 fødselsårgange har kunnet følges 10-13 år, efter de er fyldt 15 år. Undersøgelsen omfatter i alt 4.704 personer.

Den svenske undersøgelse vedrører alle registrerede lovovertrædere fra fødselskohorterne 1960, 1965, 1970 og 1975. De fleste analyser er dog alene baseret på fødselsårgang 1960, som er den årgang, der har kunnet følges længst tid til og med deres 37. år. Denne årgang består af 33.319 personer, som er registreret for en lovovertrædelse.

Spørgsmålet er, hvorvidt disse forskelle i undersøgelsesmaterialerne kan forventes at få en reel betydning for sammenligneligheden af de to undersøgelser. Dette er belyst i tabel 1, hvoraf det fremgår, at der på trods af de nævnte forskelle på en række andre områder er ganske god overensstemmelse mellem det svenske og det danske datamateriale. Fordelingen i gerningsmandskategorier er således nogenlunde ens. Bl.a. ses, at det i begge modeller lykkes at udskille en lille gruppe højaktive kriminelle. Mens de $6 \%$ kronisk kriminelle i den svenske unders $\emptyset$ gelse har begået $52 \%$ af samtlige lovovertrædelser, har de $4 \%$ kronisk kriminelle i den danske undersøgelse begået $40 \%$ af samtlige lovovertrædelser.

Det ses videre, at selv om observationsperioden i den svenske unders $\varnothing$ gelse er betydeligt længere end i den danske, er det gennemsnitlige antal lovovertrædelser og afgørelser alligevel nogenlunde ens. Det beror på det velkendte fænomen, at den kriminelle aktivitet falder med alderen, og at den danske undersøgelse omfatter den periode i personernes liv, hvor den kriminelle aktivitet almindeligvis er størst.

Tabel 1. Karakteristika ved de to datamaterialer fordelt efter lovovertrcederens kriminelle karriere.

\begin{tabular}{|l|l|c|c|c|c|c|}
\hline & & $\begin{array}{c}\text { Engangs- } \\
\text { kriminelle }\end{array}$ & $\begin{array}{c}\text { Lejligheds- } \\
\text { kriminelle }\end{array}$ & Recidivister & $\begin{array}{c}\text { Kronisk } \\
\text { kriminelle }\end{array}$ & I alt \\
\hline Antal personer & Sverige & $57 \%$ & $25 \%$ & $12 \%$ & $6 \%$ & $100 \%$ \\
& Danmark & $50 \%$ & $31 \%$ & $14 \%$ & $4 \%$ & $100 \%$ \\
\hline Antal forbrydelser & Sverige & $13 \%$ & $15 \%$ & $20 \%$ & $52 \%$ & $100 \%$ \\
& Danmark & $12 \%$ & $19 \%$ & $29 \%$ & $40 \%$ & $100 \%$ \\
\hline Antal forbrydelser & Sverige & 1,3 & 3,4 & 9,4 & 50,5 & 5,7 \\
(gennemsnit) & Danmark & 1,3 & 3,3 & 11,3 & 49,7 & 5,4 \\
\hline Antal afgørelser & Sverige & 1 & 2,3 & 5,3 & 17,8 & 2,8 \\
(gennemsnit) & Danmark & 1 & 2,3 & 5,2 & 13,1 & 2,5 \\
\hline Debutalder & Sverige & 23 & 20 & 18 & 16 & 21 \\
(median) & Danmark & 20 & 17 & 16 & 15 & 18 \\
\hline Alder seneste afgørelse/ / & Sverige & 23 & 26 & 31 & 35 & 25 \\
forhold (median) & Danmark & 20 & 22 & 24 & 25 & 21 \\
\hline Karrierelængde i år & Sverige & - & 2,2 & 4,4 & 10,4 & 2,3 \\
(gennemsnit) & Danmark & - & 3,6 & 6,5 & 9,6 & 2,5 \\
\hline
\end{tabular}


Den største forskel mellem det danske og det svenske materiale vedrører debutalder og alder ved seneste afgørelse/forhold. Ud over at den kortere undersøgelsesperiode i det danske materiale selvsagt har betydning herfor, idet fx forbryderbegyndere i 30-års alderen ikke vil være omfattet af materialet, så beror denne forskel også på, at det er alderen på gerningstidspunktet, der er anvendt $\mathrm{i}$ den danske unders $\emptyset$ gelser, mens alderen på afgørelsestidspunktet er anvendt $\mathrm{i}$ den svenske. I $\emptyset$ vrigt bemærkes klare forskelle mellem de forskellige gerningsmandskategorier med hensyn til debutalderen.

De væsentligste problemer med det danske datamateriale i forhold til det svenske synes ikke at vedrøre selve dataene, men derimod omfanget heraf. Det betydeligt mindre danske materiale skaber, som det vil fremgå af det følgende, nogle problemer for analyser, hvor personerne opdeles i en lang række undergrupper. På trods af disse begrænsninger kan den danske undersøgelse dog alligevel være med til at illustrere problemstillingen om forudsigelse af recidiv ud fra arten af de første kriminelle handlinger.

\section{Den første lovovertrædelse}

Den svenske undersøgelse har vist, at såfremt biltyveri (tilgrepp av fortskaffningsmedel) er den første lovovertrædelser, er der forholdsvis stor risiko for, at personen vil udvikle en omfattende kriminel karriere. Tilsvarende synes ikke at være tilfældet i Danmark, idet der blandt de danske biltyve er forholdsvis mange engangskriminelle og en mindre andel kronisk kriminelle end i det svenske materiale, jf. tabel 2. Det bemærkes dog også, at såvel biltyveri som flere af de andre kriminalitetskategorier vedrører forholdsvis få personer i det danske materiale, hvorfor tallene er forbundet med nogen usikkerhed.

Tabel 2. Arten af første hovedsigtelse i de to datamaterialer fordelt efter lovovertraderens kriminelle karriere.

\begin{tabular}{|l|l|c|c|c|c|c|c|}
\hline & & $\begin{array}{c}\text { Engangs- } \\
\text { kriminelle }\end{array}$ & $\begin{array}{c}\text { Lejligheds- } \\
\text { kriminelle }\end{array}$ & $\begin{array}{c}\text { Reci- } \\
\text { divister }\end{array}$ & $\begin{array}{c}\text { Kronisk } \\
\text { kriminelle }\end{array}$ & $\begin{array}{c}\text { I alt } \\
(\%)\end{array}$ & $\begin{array}{c}\text { I alt } \\
\text { (N) }\end{array}$ \\
\hline Misshandel & Sverige & $56 \%$ & $25 \%$ & $14 \%$ & $5 \%$ & $100 \%$ & 1222 \\
\hline Vold & Danmark & $38 \%$ & $33 \%$ & $22 \%$ & $7 \%$ & $100 \%$ & 87 \\
\hline Stöld & Sverige & $36 \%$ & $27 \%$ & $21 \%$ & $16 \%$ & $100 \%$ & 3212 \\
Indbrud & Danmark & $28 \%$ & $34 \%$ & $23 \%$ & $14 \%$ & $100 \%$ & 247 \\
\hline Tyveri i øvrigt & Danmark & $43 \%$ & $32 \%$ & $21 \%$ & $4 \%$ & $100 \%$ & 219 \\
\hline Snatteri ${ }^{1}$ & Sverige & $65 \%$ & $22 \%$ & $9 \%$ & $4 \%$ & $100 \%$ & 2923 \\
\hline Butikstyveri & Danmark & $64 \%$ & $21 \%$ & $11 \%$ & $4 \%$ & $100 \%$ & 357 \\
\hline Tilgrepp av fortskaff.medel & Sverige & $23 \%$ & $22 \%$ & $28 \%$ & $27 \%$ & $100 \%$ & 713 \\
\hline Biltyveri & Danmark & $33 \%$ & $26 \%$ & $25 \%$ & $16 \%$ & $100 \%$ & 80 \\
\hline Rán & Sverige & $41 \%$ & $27 \%$ & $13 \%$ & $19 \%$ & $100 \%$ & 63 \\
\hline Røveri & Danmark & $44 \%$ & $33 \%$ & $22 \%$ & $0 \%$ & $100 \%$ & 9 \\
\hline Skadegörelse & Sverige & $46 \%$ & $33 \%$ & $16 \%$ & $5 \%$ & $100 \%$ & 1200 \\
\hline Hærværk & Danmark & $54 \%$ & $28 \%$ & $14 \%$ & $3 \%$ & $100 \%$ & 90 \\
\hline Bedrägeri & Sverige & $53 \%$ & $26 \%$ & $15 \%$ & $6 \%$ & $100 \%$ & 1738 \\
\hline Bedrageri m.v. ${ }^{2}$ & Danmark & $65 \%$ & $24 \%$ & $8 \%$ & $3 \%$ & $100 \%$ & 117 \\
\hline Rattfylleri & Sverige & $59 \%$ & $26 \%$ & $11 \%$ & $4 \%$ & $100 \%$ & 2449 \\
\hline Spirituskørsel & Danmark & $65 \%$ & $28 \%$ & $6 \%$ & $1 \%$ & $100 \%$ & 253 \\
\hline Övriga trafikbrott & Sverige & $61 \%$ & $25 \%$ & $10 \%$ & $4 \%$ & $100 \%$ & 8801 \\
\hline Andre færdselsovertr. & Danmark & $50 \%$ & $34 \%$ & $12 \%$ & $4 \%$ & $100 \%$ & 2636 \\
\hline Narkotika & Sverige & $48 \%$ & $27 \%$ & $15 \%$ & $10 \%$ & $100 \%$ & 670 \\
\hline Narkotika, lov om euf. st. & Danmark & $49 \%$ & $30 \%$ & $14 \%$ & $7 \%$ & $100 \%$ & 132 \\
\hline
\end{tabular}


I den danske undersøgelse er tyveri (ud over butikstyveri) opdelt efter, om det vedrører indbrud eller ej. Det er gjort, fordi en tidligere undersøgelse har peget på, at indbrudstyveri hyppigt er forbundet med en omfattende kriminel karriere (Kyvsgaard 1995). Det ses da også, at forholdsvis mange af dem, der debuterer med indbrudstyveri, er kronisk kriminelle. Indbrud er dog på den anden siden ikke en bedre indikator på en omfattende kriminel karriere, end biltyveri er. Generelt lykkes det ikke i den danske undersøgelse i samme grad som i den svenske at pege på kriminalitetsarter, som i særlig grad er i stand til at forudsige en omfattende kriminel karriere.

Et vigtigt element ved undersøgelsen er imidlertid også at pege på, hvilke kriminalitetsformer der i særlig grad er dårlige indikatorer på en fortsat kriminel karriere. På dette område er der stor overensstemmelse mellem den svenske og den danske undersøgelse, idet begge viser, at butikstyveri sjældent tyder på, at en kriminel karriere er under udvikling. Der er end-videre nogenlunde konsensus vedrørende bedrageri, spirituskørsel og $\emptyset$ vrige færdselslovsovertrædelser som usikre indikatorer på fortsatte kriminalitetsproblemer.

Såfremt debutkriminalitet defineres som første lovovertrædelse, dvs. gerningsdatokriteriet, i stedet for som første hovedsigtelse ændres arten af debutkriminalitet for $31 \%$ af de kronisk kriminelle i den danske undersøgelse. Det er således ikke helt betydningsløst, hvilket kriterium der anvendes for debutkriminalitet.

\section{Den anden afgørelse}

I den svenske undersøgelse er der også set på prædiktionsværdien af den hovedsigtelse, der indgår i den 2. strafferetlige afgørelse. De tre former for debutkriminalitet, der viser stor risiko for fortsat kriminel karriere i den svenske undersøgelse - nemlig biltyveri, tyveri og røveri - går igen, når 2. afgørelse tages i betragtning, jf. tabel 3. Biltyveri som indikation på fortsat kriminalitet bliver blot endnu mere markant ved anden afgørelse.

Den danske undersøgelse viser, at først og fremmest indbrud er forbundet med en forholdsvis stor risiko for fortsat kriminalitet, men der er dog langt fra tale om en sikker prognose, idet sandsynligheden for en kort kriminel karriere er større. Forskellen mellem den svenske og den danske undersøgelse med hensyn til fordelingen af biltyverier bliver noget tydeligere ved anden end ved første afgørelse, og det understreger, at biltyveri næppe diskriminerer så klart mellem forskellige karrieretyper i Danmark, som tilfældet er i Sverige.

De kriminalitetsarter, der - på baggrund af den anden hovedsigtelse - relativt sjældent er forbundet med en omfattende kriminel karriere, er primært de forskellige former for færdselslovsovertrædelser, men også butikstyveri, vold og hærværk er forholdsvis dårlige indikatorer på en langvarig kriminel karrierer. 
Tabel 3. Arten af anden hovedsigtelse i de to datamaterialer fordelt efter lovovertraderens kriminelle karriere.

\begin{tabular}{|c|c|c|c|c|c|c|}
\hline & & $\begin{array}{c}\text { Lejligheds- } \\
\text { kriminelle }\end{array}$ & $\begin{array}{c}\text { Reci- } \\
\text { divister }\end{array}$ & $\begin{array}{c}\text { Kronisk } \\
\text { kriminelle }\end{array}$ & $\begin{array}{l}\text { I alt } \\
(\%)\end{array}$ & $\begin{array}{l}\text { I alt } \\
(\mathrm{N})\end{array}$ \\
\hline $\begin{array}{l}\text { Misshandel } \\
\text { Vold }\end{array}$ & $\begin{array}{l}\text { Sverige } \\
\text { Danmark }\end{array}$ & $\begin{array}{l}61 \% \\
53 \%\end{array}$ & $\begin{array}{l}29 \% \\
32 \%\end{array}$ & $\begin{array}{l}10 \% \\
15 \%\end{array}$ & $\begin{array}{l}100 \% \\
100 \% \\
\end{array}$ & $\begin{array}{c}756 \\
74 \\
\end{array}$ \\
\hline Stöld & Sverige & $37 \%$ & $32 \%$ & $31 \%$ & $100 \%$ & 1691 \\
\hline Indbrud & Danmark & $36 \%$ & $36 \%$ & $28 \%$ & $100 \%$ & 130 \\
\hline Tyveri i øvrigt & Danmark & $50 \%$ & $36 \%$ & $14 \%$ & $100 \%$ & 111 \\
\hline Snatteri & Sverige & $61 \%$ & $28 \%$ & $11 \%$ & $100 \%$ & 961 \\
\hline Butikstyveri & Danmark & $57 \%$ & $36 \%$ & $7 \%$ & $100 \%$ & 111 \\
\hline Tilgrepp av fortskaff.medel & Sverige & $20 \%$ & $38 \%$ & $42 \%$ & $100 \%$ & 423 \\
\hline Biltyveri & Danmark & $43 \%$ & $40 \%$ & $17 \%$ & $100 \%$ & 58 \\
\hline Rån & Sverige & $52 \%$ & $20 \%$ & $28 \%$ & $100 \%$ & 46 \\
\hline Røveri & Danmark & $33 \%$ & $44 \%$ & $22 \%$ & $100 \%$ & 9 \\
\hline Skadegörelse & Sverige & $54 \%$ & $33 \%$ & $13 \%$ & $100 \%$ & 607 \\
\hline Hærværk & Danmark & $61 \%$ & $31 \%$ & $8 \%$ & $100 \%$ & 75 \\
\hline Bedrägeri & Sverige & $55 \%$ & $29 \%$ & $16 \%$ & $100 \%$ & 838 \\
\hline Bedrageri m.v. & Danmark & $71 \%$ & $22 \%$ & $7 \%$ & $100 \%$ & 69 \\
\hline Rattfylleri & Sverige & $66 \%$ & $25 \%$ & $9 \%$ & $100 \%$ & 1318 \\
\hline Spirituskørsel & Danmark & $79 \%$ & $18 \%$ & $3 \%$ & $100 \%$ & 190 \\
\hline Övriga trafikbrott & Sverige & $63 \%$ & $26 \%$ & $11 \%$ & $100 \%$ & 2754 \\
\hline Andre færdselsovertr. & Danmark & $67 \%$ & $27 \%$ & $6 \%$ & $100 \%$ & 1155 \\
\hline Narkotika & Sverige & $52 \%$ & $31 \%$ & $17 \%$ & $100 \%$ & 527 \\
\hline Narkotika, lov om euf. st. & Danmark & $57 \%$ & $28 \%$ & $15 \%$ & $100 \%$ & 75 \\
\hline
\end{tabular}

Såfremt anden hovedsigtelse erstattes med anden lovovertrædelse, altså gerningsdatokriteriet i stedet for afgørelseskriteriet, ændres arten af kriminalitet for $23 \%$ af de kronisk kriminelle i den danske undersøgelse.

\section{Kombination af forbrydelser}

Hverken den svenske eller den danske undersøgelse kan pege på forbrydelsestyper, der som første eller anden hovedsigtelse med stor sikkerhed kan forudsige en langvarig kriminel karriere. Med få undtagelser er arten af såvel den første som den anden hovedsigtelse bedst til at forudsige en kortvarig kriminel karriere - alene af den grund, at de kortvarige karrierer dominerer.

Med henblik på at få en bedre forudsigelse er der i den svenske undersøgelse set på kombinationen af første og anden hovedsigtelse. Det er her, ovennævnte interessante resultat viser sig, nemlig at kombinationen af biltyveri som hovedsigtelse ved både første og anden strafferetlige afgørelse med $61 \%$ sandsynlighed forudsiger kronisk kriminalitet. Dette kaldes i rapporten en højrisikokombination, og tre andre af sådanne påpeges, nemlig henholdsvis en kombination af biltyveri og tyveri eller af tyveri og biltyveri (i begge tilfælde er der 54\% sandsynlighed for kronisk kriminalitet) samt kombinationen af narkotikakriminalitet og tyveri (53\% sandsynlighed for kronisk kriminalitet). Er en af disse kombinationer til stede, er der altså tale om en større sandsynlighed for en omfattende end for en kort kriminel karriere. 
Det forholdsvis lille danske undersøgelsesmateriale bevirker, at antallet af tilfælde med de forskellige kombinationer er ganske ringe. Det skyldes endvidere, at kombinationen af færdselslovsovertrædelser som både første og anden hovedsigtelse er yderst dominerende i den danske undersøgelse, idet den vedrører $43 \%$ af alle kombinationer.

Kombinationen af biltyveri som såvel første som anden hovedsigtelse forekommer kun i 8 tilfælde i det danske materiale, og i intet tilfælde for de kronisk kriminelle. Der er 6 kombinationer i det danske materiale, som forudsiger kronisk kriminalitet med mere end 50\% sandsynlighed, men alle disse kombinationer er ret sjældne og forekommer sammenlagt kun i 18 ud af samtlige 2334 kombinationer (for alle gerningsmandskategorier). Kun én af disse kombinationer svarer til dem, der er fundet i det svenske materiale, nemlig kombinationen af biltyveri. Desuden viser det sig, at de fleste af disse kombinationer mister deres prædiktionsværdi, såfremt der ses på de to første forbrydelser (vurderet ud fra gerningstidspunktet) frem for på de to første hovedsigtelser.

\section{Forudsigelsernes begrænsninger}

Det er givet, at det forholdsvis lille danske materiale gør det usikkert at konkludere, hvorvidt kombinationer af visse former for forbrydelser reelt forekommer betydeligt oftere for kronisk kriminelle end for andre. Dog er der ikke umiddelbart noget, der tyder på, at kombinationen af biltyveri som første og anden hovedsigtelse eller som første og anden lovovertrædelse (vurderet ud fra gerningstidspunktet) vil kunne forudsige kronisk kriminalitet med en rimelig sikkerhed i Danmark.

Vigtigere er det imidlertid, at undersøgelsen tyder på, at betydningen af forudsigelser, baseret på kombination af forbrydelser, er af begrænset praktisk værdi. Det skyldes, at kombinationsmulighederne er vældig mange, og at der er en meget stor spredning i disse. Det skyldes endvidere, at såvel fordelingen af gerningsmandskategorier som af kriminalitetens art er meget skæv. Det får den effekt, at højrisikokombinationer reelt kun vedrører en mindre gruppe af de kronisk kriminelle, mens lavrisikokombinationer vedrører en større andel. Den svenske kombination, der har været så meget omtalt i den danske debat - biltyveri-biltyveri - forekommer reelt kun for mindre end $2 \%$ af de kronisk kriminelle i det svenske materiale, og samtlige af de nævnte svenske fire højrisikokombinationer vedrører tilsammen alene $9 \%$ af de kronisk kriminelle. Det vil sige, at mindre end $10 \%$ af de kronisk kriminelle vil kunne forudsiges ved brug af disse højrisikokombinationer. I det danske datamateriale vedrører de 6 ovennævnte højrisikokombinationer sammenlagt $7 \%$ af de kronisk kriminelle, mens til gengæld en lavrisikokombination, færdselslovsovertrædelser ved såvel første som anden hovedsigtelse, vedrører $25 \%$ af de kronisk kriminelle.

Set i sammenhæng med, at det selv ikke med det omfattende svenske materiale er muligt at pege på kombinationer, som med en meget stor sandsynlighed 
udpeger kronisk kriminelle - de fleste højrisikokombinationer giver kun godt $50 \%$ sandsynlighed for kronisk kriminalitet - forekommer metoden dermed at være af ringe praktisk betydning.

\section{Noter:}

Omfatter tyveri af varer til en værdi op til 100 SEK.

2 Omfatter også underslæb, mandatsvig, afpresning, åger og grov skattesvig.

\section{Litteratur}

Andersson, Jan. 1991. Kriminelle karriärer och påföljdval. Stockholm: Project Metroplitan, no 35. BRÅ-rapport. 2000. Strategiska brott. BRÅ-rapport 2000:3. Stockholm: Fritzes.

Cohen, Jacqueline. 1983. "Incapacitation as a Strategy for Crime Control: Possibilities, and PitfalIs." I M. Tonry \& N. Morris (eds.): Crime and Justice. An Annual Review of Research, vol. 5, pp. 1-84. Chicago: The University of Chicago Press.

Farrington, David P. 2001. "Key Results from the First Forty Years of the Cambridge Study in Delinquent Development." I T.P Thornberry \& M.D. Krohn (eds.): Longitudinal Research in the Social and Behavioral Sciences. New York: Kluwer/Plenum, in press.

Greenwood, Peter. 1982. Selective Incapacitation. Santa Monica: Rand Corporation.

Hurwitz, Stephan og Karl O. Christiansen. 1971. Kriminologi II. København: Gyldendal.

Kyvsgaard, Britta. 1995. "Kriminel og social belastning blandt indbrudstyve og narkotikakriminelle." I F. Balvig \& A. Snare (red.): Årbog 1994. København: Kriminalistisk Institut.

Kyvsgaard, Britta. 1998. Den kriminelle karriere. København: Jurist- og Økonomforbundets Forlag. Weis, Joseph G. 1986. "Issues in the Measurement of Crimial Careers." I A. Blumstein, J. Cohen, J. A. Roth \& C. A. Visher (eds.): Criminal Careers and "Career Criminals", vol. 2, pp. 1-51. Washington: National Academy Press.

Adresse: Justitsministeriet

Slotsholmsgade 10

DK - 1216 København K. 